\title{
Reflections
}

\section{Taqlid and Ijtihad}

\section{Tàhā J. al Alwānì}

\section{The Polemics of Ijtihad}

From the second hijri century until the present day, the reality, the essence, the rules, the conditions, the premises, the means, and the scope of ijtihad have remained a source of debate engaging some of the Islamic world's greatest theologians, scholars of al ușül, and fuqahä.' This debate has also been enriched by proponents of the view that the door of ijtihad was closed and that the fiqh left by the Four Imams obviated the need for any further ijtihad, as well as by those who claimed that this door was still open and that the existing fiqh was not sufficient to guide the contemporary Muslim world.

In our own times, attention is now focused on the suitability of the Shariah as an order and a way of life. This new topic of debate, before unknown among Muslims, emerged after the crushing defeats experienced by the Muslim ummah after the First World War, such as the dismantling of the khiläfah and the creation of artificial states ruled from Europe. Many Muslims blamed Islam and its institutions for their defeat, and soon began to emulate their conquerors. Others, however, had a quite different view: the Muslim ummah experienced these disasters because it had become alienated from the eternal truths of Islam. Thus, what was required was a return to the true Islam and not its wholesale rejection in favor of alien institutions and ideologies. One fundamental part of this return would have to be the use of ijtihad, for how else could Muslims incorporate Islamic principles into situations with which they had never had to deal?

Muslims who hold the latter view are aware of the fact that they must meet their opponents in the realm of ideas, for it is here that the future course of the ummah will be decided. To be successful, much energy must be expended in scholarship and conceptual thinking, in seeking to understand humanity's place in the divine scheme of existence and what is expected of it, and how this knowledge might be applied by Muslims as they struggle

Tähā J. al 'Alwānī is a member of the Fiqh Academy of the Organization of the Islamic Conference, chairman of the Fiqh Council of North America, and president of the International Institute of Islamic Thought in Herndon, Virginia. 
to bring themselves and their societies unto conformity with the will of Allah (SWT). Without a complete civilizational design, by means of which the ummah may by restored to its former median position and fulfill its role as being a "witness unto nations," it will never be able to regain its former position or even to make a new beginning.

Today, the Muslim ummah is in a deplorable state. No longer can it present itself as having a unique culture, system of values, personality or anything else which makes a civilization distinct from all others, for largescale borrowing from the West has undermined and distorted all of its inimitable features. It is now a travesty of its former self, and can only manage to perpetuate itself through the production of religious specialists whose academic background is limited to the personal laws of Islam alone.

However, there are some signs that change is in the air. This has taken the form of an attempt at revival, or sahwah, which is striving to raise the ummah's consciousness, to outline the features of its character, and to bring together its past and present so that it can intelligently chart its future course by way of studying its cultural personality and its civilizational components as reflected in its thought, methodology, sciences, disciplines, aesthetics, and so on.

However, none of this activity will be of any use if its end result is something other than a recognition of the fact that there is a crisis in its thought which can only be solved by a restructuring of the ummah's cultural mold and a reordering of its priorities. The only way for even the first steps to be taken is a coming together of those enlightened and capable Muslims who can see what has to be done.

An indispensable tool in this task is the exercise of ijtihad, for it can be historically shown that the Muslim ummah only entered its current crisis after ijtihad fell into disuse and was gradually replaced by taqlid.

\section{The Dynamism of Ijtihad in Restructuring Islamic Methodology (al Minhäj)}

The study of ijtihad and its principles is one of the pillars of the "Islamization of Knowledge," and as such comes within the framework of the study of a distinct "Islamic methodology." It is this methodology which will, if applied, produce a comprehensive and uniquely Islamic understanding of sociological phenomena, their agents, essential elements, and relationships, along with an appreciation of their governing laws and principles. Such a 
development is now impossible, for the current methodological foundations are all creations of the West and, as a result, are inherently hostile towards Islam and its concepts.

What is needed is the erection of an Islamic methodology which can replace its Western counterpart. This is no easy undertaking, for it involves establishing a unique framework of knowledge, defining the sources of knowledge and the rules which govern their use, and initiating a critical review of all facets of both the Western and the Islamic methodologies so that those elements which are suitable can be retained, and those which are not can be either transformed and then accepted, or rejected outright.

In addition to having to deal with characteristics of the Western model which will influence how Muslims deal with the Islamic model, there is the additional problem of having to use Western terminology. Indeed, it is next to impossible to free oneself from the categorizations and concepts upheld by Western scholarship, or from their influences, when dealing with studies of any other civilizational model. It is for this reason that most of

the scientific methodologies in the West are incapable of looking at Islam, or Islamic society and its social strata, its economics, its political order. And this is what strips such West-oriented studies of their academic integrity, so that they appear little more than presumptuous deductions based on superficial similarities. This is because it is impossible to understand Islam from the perspective of what Western scholarship presupposes in regard to organized religion. In the same way, it is unrealistic to suppose that the Islamic model of society could be understood through the categories propositioned by the Western model as a result of its own historical experience. $^{2}$

However, Muslims are fortunate in that they do not have to start from the beginning as regards this undertaking, for there is much in the classical Islamic legacy which is of use. This same legacy also provides contemporary Muslim scholars with a framework for organizing the rules relevant to the Islamic epistemological sources and for delineating the relationships between them. Thus, one may state that the level of scholarship attained by previous Muslim scholars using the methodology developed by the early mujtahidūn was extremely mature. ${ }^{3}$

${ }^{2}$ Munir Shafīq, Al Islām fi Ma'rakah al Hadārah, 12-13. See also Sayf 'Abd al Fattāḥ, Al Tajdìd al Siyāsì wa al Khibrah al Islämìyah, an unpublished doctoral dissertation submitted to the College of Economics and Political Science at Cairo University, 1987.

${ }^{3}$ Shaf iq, op. cit., p. 36. See also 'Abd al 'Aziz al Khayt, Manähij al Fuqahä' (Cairo and Damascus: Dār al Salām, 1406/1986), 7. 
As we consider the Islamization of Knowledge to be one of the higher purposes of Islam, as well as a living and civilizational necessity, the need for ijtihad becomes obvious. Not only is it required for the creation of an Islamic methodology, but it also has a pivotal role to play in a Muslim's daily life, in the formation of a spiritually, mentally, and intellectually balanced Muslim personality which can assume the role of Allah's vicegerent, and pursue the ummah's best interests. Thus its correct exercise, in conformity to the specified conditions, is extremely important.

This illustrates a fundamental difference between the two types of Muslims which we see today. One group accepts the viewpoint outlined above, while the other rejects it and calls for the wholesale adoption of Western knowledge. This latter group, frequently referred to as reformers, has yet to acquire an appreciation for the differences between Islam and the West, differences that sometimes reach the point of outright contradiction. ${ }^{4}$

As we have noted earlier, the role of ijtihad in freeing the Muslim ummah from its bondage to the West is primary. It is only through the use of ijtihad that Muslims will be able to construct a new methodological infrastructure capable of replacing the current Western one, one which will allow Muslim scholars to once again base their knowledge and epistemological paradigms upon the original sources of Islam. The degree to which we can accomplish this task is directly related to the amount of success we will have in freeing ourselves of Western domination. ${ }^{5}$ No efforts in this field will be wasted, for they are investments in the future of Islam, and may eventually provide solutions to the apparent contradictions which bedevil us today: traditionalism versus modernism; classical thought versus contemporary thought; the material world versus the afterlife; science versus religion, and others.

Many of the current theories dealing with Islamic thought are in need of definition, perspective, and proper points of departure, for without a proper methodology and a clear overview they appear to be the result of muddled and opaque thinking. The resulting theories are repeated and restated, and discussed again and debated, and finally are treated to solutions either imported from abroad or inherited from the past. Thus, nothing gets settled, solved, or agreed upon, which is certainly an intolerable situation. For Muslims, ijtihad provides the way out of this morass.

${ }^{4}$ For a more detailed discussion of the matter, see Islamization of Knowledge: General Principles and Work Plan (Herndon, VA: International Institute of Islamic Thought, 1409/1989).

${ }^{5}$ For the distinction between praiseworthy and blameworthy differences (ikhtiläf), see al Shāfi'i, Al Risālah ed. Aḥmad M. Shākir (Cairo: Al Halabī and Sons, 1940), 560; al Shäfí ì, Jimā' al Ilm, ed. Aḥmad M. Shākir, (Cairo: n.d.); and Tāhā J. al 'Alwānī, Adab al Ikhtiläf fi al Isläm (Herndon, VA: International Institute of Islamic Thought, 1987). 


\section{A Panoramic Assessment of the Progression of Ijtihad}

In this study, we would like to evaluate previous studies and extract what is useful. Also, we would like to discuss the use of ijtihad from being the preserve of the few to one suited to the needs of all qualified scholars and thinkers in the ummah. This is done in the hopes that it may be the catalyst needed to help the ummah break through the barriers preventing it from creating its own cultural, scientific, and epistemological frameworks and then regaining its former position in the world community.

In classifying previous studies of taqlid and ijtihad, we may say that they fall into two general categories: 1) Specialized Ușül Studies, and 2) Nonspecialized Studies.

In turn, the first category can be further divided into two additional categories. The first one consists of comprehensive works on ușül al fiqh in general, meaning those works dealing with source evidence and how legal rulings are derived from it, and with the status of the mujtahid or muqallid who derives such rulings. Regardless of the author's madhhab or whether he wrote in the style of a mutakallim or a faqih, or in a combination of both, these works have changed little over the centuries. Nearly every work contains a book, a chapter, or a subchapter on ijtihad and taqlid. The topics discussed nearly always include the reality (haqiqah) of ijtihad, the different kinds of ijtihad, the ijtihad of the Prophet (SAAS), whether or not every mujtahid is right, and similar complicated, technical matters concerning the principles of ijtihad and the way they are applied for obtaining legal rulings.

The second one consists of books written specifically on ijtihad. In classical times, this kind of study closely resembled the type of studies found in the first category. The main difference, however, is that where the comprehensive works of ușül al figh are brief in their treatment of the subject, these works explain at length those points which the comprehensive works only summarized, provide instances and examples, and even add new topics such as "Closing the Door of Ijtihad," "Partial Ijtihad," "Ijtihad within a Madhhab," and so on.

Nonetheless, the two categories are alike in their presentation of ijtihad from a purely descriptive perspective. ${ }^{6}$ This manner of treating ijtihad makes it a complex, specialized exercise limited and qualified by its means, methods, and conditions. ${ }^{7}$ Thus, it is no longer a creative and contemplative endeavor,

"Abd al Rahmān al Mahallāwi, Tashìl al Wușūl ilā Ilm al Ușūl, (Cairo: Muștafã al Bābī, n.d.), 8-9.

${ }^{7}$ See Al Shaykh al Murșafi, Bughyat al Muhtäj (Cairo, Maktabah al Azhār, n.d.), no. 1442 , p. 4. 
but rather a technical one, limited in its methodology and means, and restricted in the scope of its concern.

The nonspecialized studies, on the other hand, deal with ijtihad as an expression of a human intellectual and creative activity seeking to understand humanity, life, the universe, and creation. As such, it views taqlid as a rigid and negative force.

These nonspecialized sources may be described as generalized social studies, for they deal with matters of concern to the entire ummah, such as its mental and intellectual state, the history of its culture and thought, its inertia and backwardness, and its failure to contribute anything new to the contemporary world. Thus, this group is clearly distinguished from the former one by its understanding of ijtihad not in the strict terminological sense, but rather in the wider lexical sense of the expenditure of intellectual effort, in the sense of a uniquely creative mental state diametrically opposed to the prevailing intellectual rigidity found among Muslims.

These studies will often speak of the closing of the door of ijtihad and the subsequent opening of the way for taqlid, and then attempt to project this as symptomatic of the entire ummah's mentality. But they are often surprised by others who claim that the door of ijtihad was never closed and that the final rulings have not been made. It is at this point in the discussion that the larger focus usually gets lost, for participants then begin the endless debate over the exact status of ijtihad, who can or cannot use it or close the door, and other ancillary matters. Regardless of all of the arguments presented by both sides, the fact remains that regular ijtihad has not been practiced for centuries, despite its very rare use by individual fuqahà ', and that the intellectual and cultural conditions of the ummah have not been very conducive to its use.

These nonspecialized studies may also be further subdivided into two categories: secular and nonsecular. The first group consists of works by Muslim secularists, writing in Arabic, which present revival and modernity, in the Western sense of those terms, as cures. Many of their arguments come from the European Age of Enlightenment, a time of intense anti-Church feeling. Their use of such arguments have caused them to view Islam and Christianity, mosque and church, faqih and cleric as one and the same, which leads to their further assumption that Muslims need a Renaissance to free themselves from these shackles so that they can follow the Christians down the road of progress, which of course includes secularism. They regard ijtihad as tailormade for this endeavor for, once it has been stripped of its lexical and juridical meanings and made synonymous with one's personal opinions and inclinations, the path of the West can be followed quite easily.

However, those very people who stretched the meaning of ijtihad to the breaking point to justify their dream of modernization and Westernization 
now find themselves hard-pressed to conceal the shallowness of their thought, or the crisis of their identities, and so have started to use other means and terminologies, both contemporary and classical, to accomplish their goal. Such writings are unmistakable for the kind of symbolism they employ and the folly, they espouse. ${ }^{8}$

The second group consists of works by Muslims who believe that the ummah is passing through a period of intellectual crisis which can only be ended by the recovery of its pristine character, the reform of its inner life, the reshaping of its mentality, and the building up of its individuality. In their opinion, the ummah reached its present deplorable state only after its members had stopped making relevant and intelligent contributions to its daily life.

This group also eventually comes around to the same discussion mentioned above as engaging the first group of writers, but only after passing through the following steps: the rationalists (ahl al ra'i) versus the traditionists ( $a h l$ al hadith), the codification of fiqh-oriented ijtihad, and the history of the call to end further ijtihad and accept the legal authority of the four Sunni Imāms of fiqh or taqlid - a truly barren landmark in the ummah's intellectual life, as well as the starting point of its present intellectual crisis and cultural decay.

Then the discussion about the opening and closing of the door of ijtihad begins. Some participants, however, fail to realize that the overall intellectual and cultural climate of the ummah is one matter, and that the discussion of ijtihad's lack of movement in one limited field (i.e. fiqh) among the many fields of knowledge is an entirely different matter. Thus, discussion turns into controversy among those who insist that the door of ijtihad was closed and those who insist that it was not.

In my estimation, the majority of those who claim that the door of ijtihad is closed are in reality pointing to the fact that the ummah's intellectual contribution to the social sciences has ended, while the second group is coming from the angle that the collected corpus of fiqhi literature is still able to address current problems, regardless of whether legal decisions are issued or not. Nonetheless, fiqhī questions are essentially questions about details. Thus, if one scholar refuses or is unable to make a legal decision, another will

${ }^{8}$ Among the stranger instances of ijtihad undertaken by such writers is their transferral of the day and the duty of the jumiah prayer to Sunday in Western countries where Sunday is nearly universally a holiday. Likewise, some of these writings have proclaimed that Muslims may now eat pork, for pigs are raised under carefully controlled conditions, whereas during the time of the Prophet they were allowed to run free. Another instance of this type of "ijtihad" is the opinion that polygamy is allowable only for the guardians of orphans, as they are the only ones mentioned specifically in the verse that legislated polygamy. A further instance is the denial of jihad as one of the principles of Islam. 
do so on the basis of earlier fatāwa , through the application of basic principles, in consonance with the higher purposes of the Shariah, or on the basis of analogy (qiyās). The point is that this is not the matter of contention. Rather, the crisis is in regard to absolute and unrestricted ijtihad, to open minds, structured thought, and comprehensive vision, all matters without which the ummah will be unable to build a viable society or to serve as a "witness among nations."

Regardless of its apparent current abeyance, in its strictly legal sense (i.e., ijtihad being the knowledge of juridical source methodology, the rules for deriving legal rulings, and the ways of indicating legal preference), the practice of ijtihad never came to a complete halt. Even in our own time, fatâwā dealing with legal problems continue to be issued. However, this does not balance out the occurrence, from a very early date, of an unhealthy intellectual and psychological state of mind, one which did not come about through a sultan's decree, government legislation, or the lethargy of one or more scholars. On the contrary, this situation is the result of several factors, and as the crisis worsened its ill effects spread to every aspect of life, including the fiqhi aspect. As the mujtahid played an essential role in Islamic civilization and may be regarded as the Muslim version of what the West would call a "Renaissance Man," the ummah's scrutiny of the role of fiqh and of the fuqahä' in its crisis are perfectly legitimate and understandable.

\section{The Traditional Role of the Faqih}

Historically, the fuquhà ' formed a major pillar of Islamic society. Trained as scholars of the Qur'an and the Sunnah so that they could use ijtihad when dealing with religious and temporal problems, such people were the ummah's fundamental guarantee that its leaders would not lead it astray. In a sense, these people were the equivalent of such major contemporary institutions as the Congress and the Senate, and performed the check and balance function of a federal judiciary system vis-a-vis the government's executive and legislative wings. Moreover, their voice was always a moral force for enjoining good and forbidding evil.

The traditional scholar never waited for someone to come along and "award" him a degree that qualified him for the exercise of ijtihad. On the contrary, this status was achieved by dint of his own study, travels, instruction, and by keeping the company of the learned. When he judged himself ready, he would choose a pillar in the mosque, face the public, and begin his discourses. His resulting success or failure depended upon his responses to the questions of other scholars and of his students, the use of his knowledge and ability in the field of ijtihad and the solving of new problems, and the 
acceptance or rejection of his published works and decisions by his peers and the society at large. If his views were accepted, what he viewed as being correct would gradually become part and parcel of the general public's mentality and psyche, while what he viewed as incorrect would be rejected.

\section{The Role of the Faqih in the Judiciary System}

Muslim scholars were the overseers of the judiciary system (al qadā') as well as the protectors of the ummah's rights vis-a-vis its rulers. Not only were they entrusted with the task of making sure that the rulers did not transgress their proper bounds, but they were also expected to force such rulers who did go astray to mend their behavior. Thus, scholars have always been seen by the ummah as protectors of the ummah and its rights. And so when it seems that the scholars have stopped fulfilling these functions, thus bringing upon the ummah many problems and disasters, it is only logical for the average Muslim to blame all misfortunes on the scholars. It does not appear unreasonable for them to assume that the scholars' inability to perform ijtihad lies at the root of all the ummah's current backwardness, lack of contribution to contemporary humanity, and its muddled methodology.

\section{The Faqih as a Social Scientist}

The time has now come, however, for the ummah to realize that the contemporary faqih is essentially another of the social scientists so badly needed by the ummah. While he cannot replace other social scientists, they also cannot replace him. Moreover, the traditional role of the faqih can now only be undertaken by institutions dealing with educational, research, public management, supervisory, or moral-advisory matters. It is clear that the ummah needs such institutions to give order to its life, to direct its movements, to oversee its various policies and directions, and to watch over the education and psychological well-being of all Muslims. Life today is so complex that it is entirely unrealistic to expect one faqi h to master all of the knowledge needed to deal with it. What is needed is the establishment of academic committees and academies that combine the various disciplines, including the fiqhi disciplines.

\section{Unresolved Issues of Ijtihad}

I have gone through nearly one hundred and sixty studies, research papers, 
and articles dealing with taqlid and ijtihad, in addition to numerous chapters dealing with these subjects in books of fiqh, al ușül, and the history of Islamic law. At the end of this work, I shall provide the reader with a complete bibliography of these works. ${ }^{*}$ Despite the number and variety of these studies, I have noticed that almost all of them follow the same path laid down in the fourth and fifth hijri centuries by the authors of the classical compendiums of $u s \underline{u}$ l al fiqh. Moreover, these studies confine themselves to the same issues tackled by classical scholars, such as the meaning of ijtihad and taqlid, the categories of ijtihad and how they are divided, the relation of ijtihad and taqlid to certain other related concepts, the essential conditions for the exercise of ijtihad, how at present there are no mujtahidūn, how ijtihad has become fragmented, correct and incorrect ijtihad, and so on. At most, some of these studies may differ in their inclusion of other topics, possibly because of their authors' viewpoint, or because they include different and varied examples of ijtihad.

Thus, the majority of these studies proceed along nearly the same lines, differing only in unessential matters, such as one might elaborate on what others merely indicate, or a different ordering of subjects. However, I have also noticed that many important subjects have been either entirely ignored or only mentioned in passing. Among the most relevant of these subjects are the following:

a) The historical background to ijtihad and taqlid. This background is essential for an understanding of many of the issues related to these two questions, ${ }^{9}$ such as the division between intellectual and political authority in the history of Islam and its positive and negative effects on ijtihad and taqlid; the advent of sects and doctrinal divisions (i.e., the Jabriyah, the Qadariyah, the Mu'tazilah, and others) and their positive and negative effects on ijtihad and taqlid; the growth of a Muslim public character incorporating feelings of alienation and the slave mentality due to distortions in the understanding of religion, the world, humanity, shürāa, authority, the head of state, relations between authority and citizenry, internal strife, the appearance of heretical thought and politics, and the effects of all this on ijtihad and taqlid; and the lack of those institutions necessary for the establishment of the requisite methodological consciousness, which caused the consequent reliance on individual undertakings.

*This will be published in the forthcoming issues of AJISS.

${ }^{9}$ There is no denying that some of the recent studies of ijtihad and taqlid presented tentative discussions of these issues inasmuch as they at least indicated that they were important. But the fact remains that such indications, though certainly important, did no more than present these issues in a scattered and fragmentary manner. Thus, they were not placed within the framework of an overall scheme for the study of taqlid and ijtihad, or for understanding, in a renewed and comprehensive way, the core issues involved in such a study. 
b) The connection between ijtihad and the higher objectives (maqāșid) of the Shariah. Many of these studies have failed to illustrate either the affinity between ijtihad and the maqāșid of the Shariah, or the antipathy between taqlid and the maqāsidi. The only exceptions have been works dealing exclusively with the question of the maqāșid in an attempt to bring attention to the essential connection between ijtihad in its general sense and ijtihad as related to the maqāsid of the Shari'ah. ${ }^{10}$

c) The effect of multiple trends in ijtihad, how this effects the understanding of the issues of the "Oneness of Truth, Reality, and What is Correct" are understood, the clarification of the true parameters of the controversy regarding this issue, and its important intellectual, psychological, and educational consequences on the Muslim mind. Moreover, this subject requires minute attention, for it deals with the most important factors leading to the realization of actual multiplicity in ijtihad, for its clarification of the truth behind differences of opinion (ikhtiläf), and for its task of distinguishing between two different kinds of ikhtiläf, i.e., differences of diversity and differences of contradiction, or in other words, praiseworthy and permitted differences, and blameworthy and prohibited differences. Likewise, most studies dealing with ijtihad and taqlid do not pay enough attention to the question of the "Oneness of the Truth" and differences among the scholars as to exactly what this means and entails. Also missing is any concern for the potentially dangerous effects of not placing this issue in its proper perspective in order to spare the ummah any damaging negative thinking.

d) None of these books have presented a realistic and practical solution to the present crisis of ijtihad, or have dealt with the possibilities of "group" ijtihad or the establishment of research institutions and academic organizations to support such an undertaking. The absence of any solution has left the field wide open for those who wish to create and then impose man-made legislation derived from their own understanding, which may or may not include the relevant fiqhi literature, on the ummah.

e) The question of fiqh al wāqi' (real-world fiqh), its contributory factors, and the necessity of linking it with ijtihad has been ignored. As the fiqh al ahkäm was therefore not dealt with in a satisfactory manner, the circumstances surrounding the formation of the ruling in question (i.e., the occurrence itself, the time, the place, and the human element) were overlooked. This, in turn, resulted in many scholars understanding the entire process of

${ }^{10}$ Muwāfaqāt al Shātibì wa Maqāșid al Sharīah by Shaykh Muhammad al Tāhir ibn al 'Ashür, and Maqāṣid al Sharỉah by 'Allāl al Fāsī are two examples of such works. There are several recent dissertations and graduate level studies on the subject as well, such as al Ahdäf al Ämmah to al Sharíah al Islämīyah by Dr. Yüsuf al 'Ảlim, soon to be published by the International Institute of Islamic Thought, and Nazariyāt al Maqäșid inda al Imäm al Shätibì by Dr. Ahmad al Ra'isūnī, published in Morocco by the International Institute of Islamic Thought. 
ijtihad in only a partial manner, which caused them to place it under fiqh al ahkām as rulings derived from linguistic and lexical studies, rather than under fiqh al wäqi where it belongs, without proper reference to the one to whom the judgment will apply (the mahküm 'alayhi) in his/her capacity as one of the most important elements in the overall process of ijtihad.

f) Many of these studies have not gone into the details of taqlid as it applies to the individual, nor have they presented an explanation of how ijtihad relates to the individual in question. Is the relationship completely negative, as the majority of studies would suggest, or is there some scope for a positive role? If so, what would be the nature of that role, not to mention the role itself? The study of such details is part of the study of the mahküm alayhi as an element in the process of ijtihad, for surely the individual is one of its aspects. The individual is also an invaluable source of information for acquiring a proper understanding of fiqh al wäqi $i^{\prime}$ and its constituent elements, not to mention a representation of the domain in which the resulting rulings are to be applied. Thus, we can see the importance of regularizing and defining the individual's role vis-à-vis ijtihad.

g) The element of continuous self-renewal through meeting and adjusting to changing circumstances based upon rulings conducted within the framework of ijtihad is missing in many of these works. This might be due to ijtihad's being considered a purely legalistic and legislative function, thereby severely limiting its traditional and intended role. Without the addition of this element, and without a real understanding of the ties that bind the sources of Islamic thought and culture to the dynamics of ijtihad and the realities currently facing it, the ummah is destined to remain where it is, mired in hopelessness and stagnation. ${ }^{11}$

h) The necessity of clarifying concepts. Ijtihad is one of several fundamental Islamic concepts to have been either misused or misunderstood by Muslims. At present, there are essentially two interpretations of the term: it is either a technical and limited fiqhi exercise for the qualified few to the exclusion of everybody else, or it is represented by all new thoughts and ideas, regardless of whether their holders are qualified to exercise ijtihad or not.

${ }^{11} \mathrm{Among}$ the studies that have dealt with this issue are the following:

1. Muhammad Muștafā Al Marāghī, Al Ijtihäd fi al Isläm (Cairo: Al Maktab al Fannī Li al Nashr, 1379).

2. Mu'tamar al Fiqh al Islāmi, Al Ijtihäd fí al Sharíah al Islämìyah (Saudi Arabia: Jämiłah al Imām Ibn Sa‘ūd al Islāmīyah, 1401/1981).

3. Al Mūsāwī, Al Naṣs wa al Ijtihād, ed. Abū Mujtabā (Beirut: Al Dār al Islāmīyah, 1404).

4. Rị̣ā al Sadr, Al Ijtihād wa al Taqlid (Beirut: Dār al Kitāb al Lubnānī, 1976).

5. Muhammad Ibrähīm Shaqrah, Al Ra î al Sadìd fi al Ijtihäd wa al Taq İd, 1401/1981.

6. Aḥmad Ibrāhìm 'Abbās al Darāwī, Nazarìyat al Ijtihād fí al Sharíah al Islämìyah (Jeddah: Dār al Shurūq, 1403/1979). 
It seems that neither the strict nor the liberal interpretations of ijtihad have given us this term's true meaning. Also, might there not be other interpretations, such as the one represented by the group which believes that the Four Imams have sufficiently done this duty, thereby obviating it for the ummah at large? Or what about those who say that the entire fiqhi legacy must be discarded and replaced by a new one not necessarily based upon the traditional principles and guidelines established earlier, or the group which believes that the reason for the ummah's downfall is that a gulf has opened up between it and the reality of Islam? This latter group, while well aware of what needs to be done to restore the ummah to its former position in the world community, unfortunately does not have the necessary resources and numbers needed for actually changing the course of events. In addition, the existing condition of the ummah has been so far removed from the purity of its original sources, and consequently distorted by secularism, Westernization, and the process of cultural change that no one group alone can do the job.

Given all of the above, are there any specific courses of action which will actually contribute to opening the door of ijtihad? Upon reflection, it seems that there are two. These are: a) taking into consideration all of the guidelines, rules, preconditions for the process of ijtihad, along with its higher purposes (i.e., so entrenching it in the Muslim mind that it becomes the regulator of every move made by the ummah); and b) the option advocated by the secularists and non-religious Muslims, which is to fling open the door of ijtihad as wide as possible, and interpret ijtihad in such a way that it can be used to justify the results, regardless of whether the rulings were based on traditional fiqhi criteria or not. Currently, it seems that this latter group has the upper hand, for it has found many unqualified people willing to issue the desired rulings. There are also some contemporary fuqah $\bar{a}$ ' who are more than willing to issue the rulings "requested" by those in authority. There is also a conspicuous absence from the arena of those fuqaha' who have for whatever reason chosen to remain aloof and uninvolved, in effect leaving self-proclaimed scholars free to issue their rulings. A final factor is the failure of many contemporary fuqah $\bar{a}$ ' to provide workable solutions to contemporary problems, due to their incomplete understanding of the issues or their inability to fully realize the significance of their premises and predicates. Thus, many of the rulings which are issued seem to be more applicable to an earlier age, a development which only discredits the entire endeavor and the people involved.

It is for these reasons that this study will focus on several of the previously ignored issues connected with the practice of ijtihad. The study's main goals are to place these issues within the overall context of the ijtihad process, to explain why they must be studied, to establish their validity and relevance, 
and to define them. By doing this, the establishment of a contemporary Islamic methodology based on the classical discipline of juridical source methodology and fiqh may proceed apace in putting its methodological resources to use for the treatment of those issues which must be dealt with if the goals are to be realized.

Among these issues are the following:

1. The presentation of the Islamic Theory of Knowledge and its most important elements, means, and devices, and the role of each.

2. The formulation of an exact and precise definition of the relationship between revelation (wahy) and reason, for this will help Muslims solve many of the problems arising from the relationship of knowledge to religion, and of knowledge to practice. It will also help us understand ijtihad from the perspective of reality, experience, and practice.

3. The development of an agreed upon system of argument and dialogue, respect and acceptance for differing opinions and results, and an understanding as to why this is essential if the scholars are to guide the ummah's footsteps aright.

This article is therefore presented in the spirit of being the first in a series aimed at clarifying the source methodology of fiqh and the methodology of ijtihad for the contemporary social scientist interested in applying what has been discussed in this paper to the field of Islamizing knowledge in general, and its methodology in particular. It is to be hoped that the methodology for the Islamization of Knowledge will benefit from the resulting definitions, clarifications, and organization of a discipline so that it can one day stand on a solid methodological foundation. Only if this present dream becomes a reality will it become possible for Muslim social scientists to study social phenomenon, with all the attendant diversity and complexity, with an Islamic framework and epistemological paradigm and then begin the process of rebuilding Islamic civilization on the basis of its own understanding of the social sciences. This deconstruction and subsequent reconstruction is what is needed if the Muslim ummah is ever to assume its divinely ordained position as a witness to other nations. 